\title{
Relative Effectiveness of Guided Inquiry and Demontration Methods on Students Performance in Practical Chemistry in Secondary Schools in Osun State, Nigeria
}

\author{
Irinoye, J. \\ Faculty of Education \\ Obafemi Awolowo University, Ile-Ife. \\ Bamidele, E. F. \\ Faculty of Education \\ Obafemi Awolowo University, Ile-Ife. \\ Adetunji, A. A. \\ Faculty of Education \\ Obafemi Awolowo University, Ile-Ife. \\ Awodele, B.A. \\ Faculty of Education \\ Obafemi Awolowo University, Ile-Ife.
}

\begin{abstract}
The paper investigated the relative effectiveness of Guided Inquiry Strategy and Demonstration Method on the performance of students in practical Chemistry in the secondary schools in Osun State, Nigeria. The study also examined the effects of these methods on the retention ability of the students. The study adopted the non-equivalent pre-test, post-test, control group experimental design. There were two groups; the Guided Inquiry Strategy (GIS) group and the Demonstration Teaching Method (DTM) group. The population for the study consists of all Chemistry students in Senior Secondary School two (SSSII) in Ifelodun Local Government Area, of the state. The study sample was made up of seventy eight Chemistry students in Senior Secondary School two (SSSII) in their intact classes in two public co-educational Secondary Schools randomly selected in Ifelodun Local Government Area. The instrument used for the study was Achievement Test in Qualitative Analysis (ATQA). This was used for the pretest, post-test and retention ability test of the students in qualitative analysis. Results showed that there was a significant difference in the students' performance after exposure to the treatment $(t=62.712 ; p=0.000)$. Also, students taught with the GIS performed significantly better than those that were taught with the DTM $(t=27.46 ; p=$ 0.000). The mean scores 23.52 and 11.00 for the GIS and DTM respectively). There was also a significant difference in the retention ability of the two groups $(t=13.047 ; p=$ 0.000 ), with the GIS group having better retention ability of the concept taught. It was thus concluded that Guided Inquiry Strategy is a very good teaching strategy for practical chemistry because it enhanced the performance and retention of learning.
\end{abstract}

Keywords: Guided Inquiry, Demonstration Method, Qualitative analysis and Retention test.

\section{INTRODUCTION}

Chemistry is one of the science subjects which occupy a prominent place in the school curriculum. Chemistry deals with the composition, properties and uses of matters (Ababio, 2003). Chemistry is central to vocations in health services, pharmaceuticals, petroleum and petrochemical industries, agriculture, food processing, teaching services and extractive industries, In spite of the importance and utility value of Chemistry to man, Chemistry is not being taught and presented to students in ways by which the goals of learning the subject 
would be achieved. This has resulted in poor performance year in, year out (Nwagbo 2001, Adeyemo, 2004, Adegbola, 2005). The West African Examination Council (WAEC) chief examiners' report (2010) adduced the poor performances of students in practical chemistry to inadequate exposure to practical works in their various schools.

Research studies have also indicated that some factors are responsible for students' poor performance in Chemistry. The most common factors identified were the inappropriate, uninspiring and non-innovative teaching methods and strategies adopted by teacher, (Keshinro, 1998; Akeju, 2001; Bamidele, 2003; Adeyemo, 2004; Adegbola, 2005; Adedeji, Oloyede, Bamidele and Bada 2012). They maintained that if novel teaching methods were employed in teaching the students practical chemistry, the students will perform wonderfully well. According to Adedeji et. al. (2012) unless a teacher adopts suitable strategies, and engage the students actively in the classroom, the students will continue to perform poorly in the sciences because students learn better when they are actively involved in the teaching and learning processes. Teachers must continue to organize instruction by using learner centred strategies that will facilitate learning. Educational theorists have continually emphasized the distinction between meaningful learning and rote learning. To facilitate meaningful learning, students are supposed to learn for their own sake through hands-on and minds-on metacognitive approaches, memorization leads to regurgitation of facts, poor retention ability and non transfer of knowledge all that served as evidence of lack of understanding thus cannot promote self reliance.

Observations by the researchers have discovered that in most of our secondary schools, the usual practice of most teachers is to organize practical sessions for their students some few weeks to the Senior School Certificate Examination (SSCE) in the subjects involving practicals. The students are not being exposed to intensive practical session which will make them to be well vast in the practical aspects that can help them to understand the principles involved in the various concepts in the subjects. The omnipresent challenge in teaching practical Chemistry in Senior Secondary Schools is to suggest methods of organizing instruction that will facilitate learning for majority of students. A strategy which has not been sufficiently used in basic science teaching or in their practicals is guided inquiry strategy.

Guided inquiry strategy is an approach in which students are given activities in which they develop knowledge and understanding of scientific ideas, through engaging in open-ended, student centred, hands-on tasks while the teacher acts as a facilitator. According to Eniolorunda (2007), guided inquiry is an approach to inquire whereby the teacher leads his/her students with well-formulated questions that are designed to bring students face to face with knowledge they are seeking, so that they can in effect find out such knowledge. Guided Inquiry Strategy entails students given the opportunity to find out things themselves about events and scientific ideas through asking questions, investigation, observation, and construction of reasonable explanation, sharing information and experience. The teacher provides the guidance which leads to a series of developmental stages. At the beginning stage, the teacher direct materials provide a structured model for students to progress and act independently as a group.

The purpose of guided inquiry is to provide students structured experience with scientific inquiry. According to Igelsrud and Leonard (1988), four components of guided inquiry laboratory can be identified as follows:

1. Introduction: A brief introduction in form of question and set goals is to be provided.

2. Materials: The students are given a list of available materials. 
3. Procedure: In the most structured form of guided inquiry, a step wise procedure is given. Sufficient direction should be provided. Less procedural detail encourages students to think about how the data will be collected and analyzed (Allen, Barker and Ramsden (1986). Bransford and Donovan (2005) warn against using lockstep approaches to inquiry which provide carefully constructed procedures and steps for students to follow.

4. Discussion: carefully constructed questions leads the students through data review and analysis. Students need to verify their analysis and conclusions about the topics.

The principle that learners must be actively involved in constructing personal meaning is at the core of guided inquiry activities through actively engaging in observation, imagination and reasoning. Bransford and Donovan (2005) asserted that tools and procedure are not ends in themselves but devices to promote new sights. The intrinsic motivation associated with deep learning is more likely to be activated using guided inquiry approach. Guided inquiry strategy is premised upon teaching that should be geared towards making the teacher increasingly unnecessary having developed students formal operational reasoning and learning autonomy. In quete garden @ http:/www.quete garden.com/teacher, Thomas said that a teacher is one who makes himself progressively unnecessary. There is the need for teachers to use more effective and result-oriented teaching strategies to enhance students' understanding.

Practical Chemistry (Qualitative Analysis) is a physical science that is concerned with the composition, properties, constitution and mutual interactions of different kinds of matter. It is of tremendous importance in industry since it is one of the sources of how materials are produced for human utilization. Chemistry knowledge is very useful in Medicine, Agriculture, Engineering, Pharmacy and Science Education to mention but a few. The teaching of Chemistry is therefore worth-while for meaningful living and technological development in any nation. In view of Chemistry impact and influence, chemistry should create in the learners an awareness of the impact and influence it has on the society as a means for preparing him/her for a life in technological age.

Adetunji (2007) said "The teaching of Chemistry should be based on investigation so that learners themselves discover the facts". According to Gadner, Moore and Waddington (1984) "Laboratory work is an essential component of chemical education. Students can be stuffed with facts and theories but without experiments, they cannot experience the reality of Chemistry as a science. The development of power of observation, measurement, prediction, interpretation, design and decision making are dependent on laboratory experience. Silber (1981) said that "essentials in teaching science often include good equipment, laboratory facilities, modern curriculum materials, teaching aids and limited students load". Better teaching strategy application depends upon the curriculum executors (teacher) in the teaching learning process.

Qualitative analysis deals with scientific ways of identification of chemical components that a compound, salt or substance consists of. Positively charged ions are called cations or metallic ions or basic radicals. For Senior School Certificate Examination, cations expected for identification are as follows: $\mathrm{Pb} 2+, \mathrm{Ca} 2+, \mathrm{Zn} 2+, \mathrm{Al} 3+, \mathrm{Fe} 2+, \mathrm{Fe} 3+, \mathrm{Cu} 2+$ and $\mathrm{NH} 4+$. Negatively charged ion is called anion or an acidic radical. Similarly for Senior Secondary Certificate Examination anions required for identification are NO3-, CO32-, HCO3-, SO32-, SO42-, Cl-, and S2-. There are two ways involved in the procedure for identification of chemical components, these are physical test and chemical test. Physical test is not a reliable test but only helps in suspecting a substance under test. The tests include the following (Sanda, 2005).

1. Solubility test

2. Colour test 


\section{Texture test}

4. Odour test

Chemical test involve using solution of a chemical reagents to identify component ion(s) present to give chemical substance under test. A chemical test helps in suspecting the presence and confirmation of the ion present in a substance under test with no bias or doubt. A chemical test involves use of reagents in solution.

West African Examination Council chief examiners' report (2010) succinctly outlined candidates' weakness in Practical chemistry (Qualitative Analysis) as follows:

I. Inability to carry out required test

II. Non adherence to instructions

III. Poor expressions

IV. Poor knowledge of separation techniques

V. Inability to record observation made and give logical inferences

VI. Lack of proper understanding of basic principles and concepts

VII. Inability to differentiate theoretical knowledge from practical observation

However, the following were the suggested remedies:

I. Candidates should be well exposed to practical work.

II. Laboratories should be well equipped with modern and relevant instruments and facilities.

Teaching can only be effective, meaningful, productive, consistent and enjoyable when the students are active participants. Bearing this in mind, the present study seeks to examine the effects of Guided Inquiry Strategies on Secondary School Students' Performance in Practical Chemistry - Qualitative Analysis.

The objectives of the study therefore are:

a. Examine the effectiveness of Guided Inquiry Strategy (GIS) on students' performance in Practical Chemistry

b. Determine the relative effectiveness of Guided Inquiry Strategy (GIS) and Demonstration Teaching Method (DTM); and

c. Determine the retention ability of students taught Chemistry practical (qualitative analysis) using GIS and DTM.

\section{Research Hypotheses}

From the above-mentioned objectives of the study, the following research hypotheses were generated and tested:

1. There is no significant difference in the performance of students taught using Guided Inquiry Strategy (GIS).

2. There is no significant difference in the performance of students taught the Guided Inquiry Strategy (GIS) and those taught with the Demonstration Teaching Method (DTM).

3. There is no significant difference in the retention ability of students when GIS and DTM were used in teaching Practical Chemistry (Qualitative Analysis)

\section{Theoretical Framework}

The constructivist theory is the spring board for this study. The central idea in the theory is on mental development as a result of what meaning one is able to make out of an idea and concepts one has come across. This study centers on the work of Vygotsky. 
Vygotsky, social learning constructivist offers a framework for instruction based upon the study of cognition. Vygotsky's constructivism centres on allowing students to actively interact with others. He believes that by allowing students to actively interact with one another, there will be opportunities for investigating, experimenting and asking questions, which will lead to getting answers that will make learning real and long-lasting. Vygotsky theory proffers that knowledge is situated and collaborative, therefore knowledge is distributed among people and environment.

In Guided Inquiry Strategy, students were given opportunity to find out things themselves about practical Chemistry (Qualitative Analysis). Students carry out investigation, asking questions, observation and construction of reasonable explanation in addition to sharing information and experiences while the teacher provides guidance. These will make learning real and long lasting. According to Schunk (2000):

\section{Constructivism is the notion that thinking takes places in Contexts and [that] cognition is largely constructed by Individuals as a function of their experiences in situations.... [it] highlights the interaction of persons with situations In the acquisition and refinement of skills and knowledge.... People are active learners and must construct Knowledge for themselves. p.229}

The major theme of Vygotsky's work is that social interaction plays a fundamental role in the development of cognition.

Another aspect of Vygotsky's theory is the idea that the potential for cognitive development depends upon the "Zone of Proximal Development (ZPD)". ZPD is a Vygotsky's term for the range of tasks that are two difficult for children to master alone but that can be learned with guidance and assistance from teacher. Vygotsky states that a child follows an adult's example and gradually develops the ability to do certain tasks without help or assistance. In Guided Inquiry Strategy, the teacher carries out modelling then serves as a facilitator. The students and teacher discuss and formulates conclusion on what is learnt. The learning theory proposed by Vygotsky emphasize interactive action between the students and the source of knowledge which would assist the learner to re-establish ideas in their own minds. This allows for individual active participation in practical chemistry. This is a pointer to teachers that learners' understanding of concepts during teaching process is paramount, thus teachers use star strategies that would promote learners' active participation in order to promote learning. Guided Inquiry Strategy (GIS) entails the activities of students in which they develop knowledge and understanding of scientific ideas, through creation of a classroom where students are engage in open-ended, student-centred, hands-on activities (Colburn,1996) students investigate natural phenomenon, using their background knowledge and experiences. The things students do include posing questions, solving problems and creating answers or tentative generalizations.

\section{METHODOLOGY}

The study adopted the pre-test, post-test, control group quasi experimental design. There were two groups; one of the groups was taught using Guided Inquiry Strategy (GIS). This formed (Experimental Group 1). The other group was taught using Demonstration teaching Method (DTM). This formed group 2. The design for the study is as follows:

$\begin{array}{ccccc}\mathrm{R} & \mathrm{O}_{1} & \mathrm{X}_{1} & \mathrm{O}_{2} & \mathrm{O}_{3} \\ \mathrm{R} & \mathrm{O}_{4} & \mathrm{X}_{2} & \mathrm{O}_{5} & \mathrm{O}_{6}\end{array}$




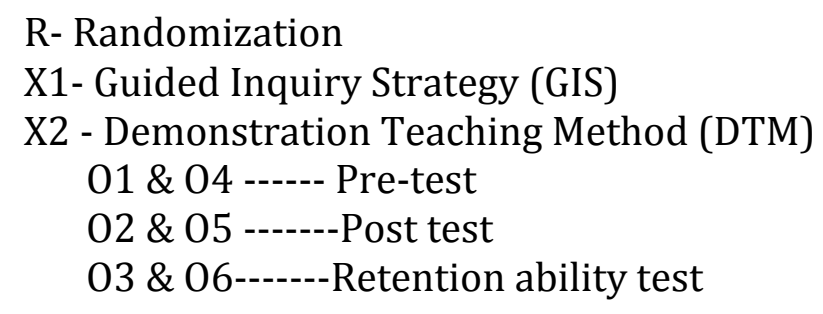

The achievement scores for students in the experimental groups during pre-test, post test and retention test scores served as the dependent variables while the treatments given to the two groups formed the independent variables.

\section{Population, Sampling Technique and Sample}

The population of the study for the study was all Chemistry students in Senior Secondary School two (SSSII) in Ifelodun Local Government Area, Osun state. The study sample consists of seventy eight Chemistry students in Senior Secondary School two (SSSII) in their intact classes in two public co-educational Secondary Schools randomly selected in Ifelodun Local Government Area, Osun-state. The schools selected are: Holy Michael Grammar School, Ikirun and Akinorun Grammar School, Ikirun.

\section{Research Instrument}

The instrument used in this study was Achievement Test in Qualitative Analysis (ATQA) designed by the researcher. The questions for this instrument were derived from past questions of the West African Examination Council (WAEC) in practical Chemistry. It is based on experiments involving qualitative analysis. The achievement test sought for students' personal information with respect to name, age, class and sex. The remaining part of the achievement test contains three practical questions which reflect the levels of knowledge, comprehension, application, analysis, synthesis and evaluation in the entire topic taught. Each item has correct answers (the key) based on correct observation and inferences from test of practical given. The test items for pre-test, post-test and retention ability test were made of same questions rearranged and with different fonts. The same achievement test was used for both groups.

\section{Validation of Research Instrument}

The instrument was validated through input from experts in Curriculum Studies and Chemistry, Obafemi Awolowo University, Ile-Ife. Based on their comments and suggestions, the original tests were screened down from five previously drafted to three practical questions. The test was then administered on 24 students of senior secondary school class II in another school apart from experimental schools. The reliability of the instrument was determined by using the Kuder Richardson Formula 20 which is 0.79.

\section{Data Collection}

The schools selected were visited by the researcher at the commencement of the term in order to obtain permission from the school authority and to be familiar with the professional colleagues. The participating schools in both schools were randomly assigned to the two strategies. The researcher familiarized the teachers with the teaching strategies to be conducted in their schools. The researcher trained the teachers on the use of GIS and DTM to be used only in their school for teaching the students. The general procedure for each teaching strategy together with the researcher's instructional guides on GIS and DTM were jointly studied and discussed in each case. 
Before the commencement of the experiment, the participants were given a thirty minutes pretest as contained in the Achievement Test on Qualitative Analysis (ATQA). Real teaching took six weeks of two periods per week. They were all taught by their different regular chemistry teachers. The researcher checked the teachers and students periodically during the treatment period to ensure that teachers were actually using the prescribed strategies. At the end of the teaching sessions, the post-test was administered. The validated marking scheme was used for marking and grading the students. The marks obtained by the students in the two groups were recorded. Retention ability test was administered after two weeks of conducting post-test. The achievement scores of students obtained in the two experimental groups during the pre-test and post-test and retention ability test served as the dependent variables. The data collected were analyzed by using descriptive and t-test statistics. The level of significance applied was 0.05 .

\section{RESULTS}

To determine the possible difference in background knowledge of the two groups, the participants were given the pre-test. The data obtained were subjected to the t-test analysis. The result obtained is presented in table 1 below.

Table 1 t-test Analysis of the Pre-test Scores of the GIS and DTM Groups

\begin{tabular}{|c|c|c|c|c|c|c|}
\hline Experimental groups & $\mathrm{N}$ & Mean & Std. deviation & Std. error mean & $\mathrm{t}$ & Sig. \\
\hline GIS & 40 & 1.150 & 0.892 & 0.141 & \multirow[b]{2}{*}{0.590} & \multirow[b]{2}{*}{0.557} \\
\hline DTM & 38 & 1.263 & 0.794 & 0.129 & & \\
\hline
\end{tabular}

From the result presented in the table, it could be seen that the value of ' $t$ ' is not significant. This indicated that there was no significant difference in the performance of the two groups before the treatment. This implies that there was no difference in the background knowledge in practical Chemistry of the students in the two groups prior to the administration of the treatment.

\section{Hypothesis One}

The hypothesis state that there is no significant difference in the performance of students taught using Guided Inquiry Strategy (GIS).

To test this hypothesis, the pre-test and post test scores of the group taught with guided inquiry strategy were compared. The result is presented in the table 2 below.

Table $2 \mathrm{t}$-test analysis of the pre-test and post-test scores of the Guided Inquiry Group

\begin{tabular}{|c|c|c|c|c|c|c|}
\hline Experimental group (GIS) & $\mathrm{N}$ & Mean & Std. deviation & Std. error mean & $\mathrm{t}$ & Sig. \\
\hline Pretest Score & 40 & 1.15 & 0.892 & 0.141 & \multirow[b]{2}{*}{62.712} & \multirow[b]{2}{*}{0.000} \\
\hline Posttest Score & 40 & 23.525 & 2.038 & 0.322 & & \\
\hline
\end{tabular}

From the table, $\mathrm{t}=62.712$ with $\mathrm{p}=0.00$ indicating that there was a significant difference in the performance of the group taught using the Guided Inquiry Strategy. Thus, the hypothesis is rejected.

\section{Hypothesis Two}

The hypothesis states that there is no significant difference in the performance of students taught with the Guided Inquiry Strategy (GIS) and those taught with the Demonstration Teaching Method (DTM). To test this hypothesis, the post test scores of the two groups were subjected to t-test analysis and the result obtained is presented in table 3 below. 
Table 3 t-test analysis of the GIS and DTM groups in their Post - test.

\begin{tabular}{|c|c|c|c|c|c|c|}
\hline Experimental groups & $\mathrm{N}$ & Mean & Std. deviation & Std. error mean & $\mathrm{T}$ & Sig. \\
\hline GIS & 40 & 23.525 & 2.038 & 0.322 & \multirow[b]{2}{*}{27.466} & \multirow[b]{2}{*}{0.000} \\
\hline DTM & 38 & 11.000 & 1.986 & 0.322 & & \\
\hline
\end{tabular}

Result showed that there was a significant difference between the performance of students taught Qualitative analysis using the Guided Inquiry Strategy and those taught using the Demonstration technique $(\mathrm{t}=27.466, \mathrm{p}=0.000)$.

Therefore, the hypothesis is rejected. Since the mean score of the GIS group is greater than that of the DTM group, 23.525 and 11.000 respectively, it implies that the GIS group performed better than the DTM group.

\section{Hypothesis Three}

The hypothesis states that there is no significant difference in the retention ability of students when GIS and DTM were used in teaching Practical Chemistry (Qualitative Analysis).

To test this hypothesis, the scores of the students in the retention test were subjected to the ttest analysis. The result is presented in Table 4 below.

Table 4 t-test analysis of the GIS and DTM groups in their Retention Test.

\begin{tabular}{|c|c|c|c|c|c|c|}
\hline Experimental groups & $\mathrm{N}$ & Mean & Std. deviation & Std. error mean & $\mathrm{t}$ & Sig. \\
\hline GIS & 40 & 22.575 & 2.782 & 0.439 & \multirow[b]{2}{*}{13.047} & \multirow[b]{2}{*}{0.000} \\
\hline DTM & 38 & 13.421 & 3.398 & 0.551 & & \\
\hline
\end{tabular}

Result indicated that there was a significant difference in the retention ability of the students with respect to the teaching approaches used, $t=13.047, p=0.000$. Looking at the mean scores, the GIS had a mean score of 22.575, while the DTM group had a mean score of 13.42. This implies that the group that was taught using the Guided Inquiry Strategy (GIS) retained the materials learnt better than the group that was taught with the Demonstration method (DTM).

\section{DISCUSSION}

On the hypothesis that stated that there is no significant difference in the performance of students taught using Guided Inquiry Strategy (GIS). Result indicated that there was a significant difference in the students' performance. The students performed better after they have been exposed to the guided inquiry strategy which implied that the two methods enhance learning. However, students that were taught with the GIS performed better in Chemistry practical than those that were taught with the demonstration method. This result is in agreement with the study by Onanuga, (2001), Nwagbo, (2001), Adegbola, (2005) and EniOlorunda, (2007). They reported that the use of guided inquiry strategy in teaching and learning science subjects is superior to use of conventional teaching method. They maintained that the nature of guided inquiry that provided for activities such as: small group activities, communication with peers, role play, feedback opportunities, knowledge sharing and joint construction of conclusions made it possible to enhance the performance of learners taught with it.

\section{CONCLUSION}

The study concluded that GIS produced a significantly better performance in Qualitative Analysis than DTM. Thus, GIS is an effective method of instruction for secondary school 
students especially in Practical Chemistry. This implies that students will learn better with strategies that involve student active participation.

\section{Recommendations}

I. Chemistry teachers need to focus their methods of instruction on students' active participation. The students should be encouraged to imbibe mental construction of knowledge on their own. Active participation of students should be allowed in practical Chemistry classroom to bring about meaningful learning.

II. Guided Inquiry Strategy should be adopted for teaching practical Chemistry in our secondary schools as they involve the students actively and makes them to retain what they have learnt. The strategy also allows for cooperative group participation among students.

\section{References}

Ababio, O.Y. (2003). New chemistry: senior secondary science series (New Edition). Africana. FEP Publisher, Nigeria. pg 425-478.

Adegbola, R.A. (2005). Effects of guided discovery and self-learning strategies on secondary school students' learning outcome in chemistry Unpublished M.Ed Dissertation of University Ibadan, Ibadan.

Adetunji, A.A. (2007). Comparative effectiveness of Laboratory Teaching Technique, Video media Instruction and Practical Manual Guide in Learning Volumetric Analysis in Senior Secondary Schools. Unpublished M.A. Ed. Thesis of Obafemi Awolowo University, Ile-Ife.

Adetunji, A.A., Oloyede, E.O., Bamidele, E.F. and Bada, T.A.(2012). Comparative Effectiveness of Video Media Instruction and Laboratory teaching Techniques in Learning Practical Chemistry in Senior Secondary Schools in Osun State. Journal of Educational and Social Research. Vol. 2. No.2. University of Perugia, Italy.

Adeyemo, O.A. (2004). Effects of two Meta Cognitive Instructional Strategies on Students' Achievement in Chemistry. Unpublished M.Ed. Dissertation of University of Ibadan, Ibadan.

Ajewole, G.A. (1990). Effects of guided discovery and expository instructional methods on students' transfer of learning. The Journal of Science Teacher Association of Nigeria, 20 (4), 59-66.

Akeju, O.A. (2001). Relative Effectiveness of Teacher Demonstration and Structural Inquiry and Gender on Students Learning Outcome in Chemistry Practical. Unpublished M.Ed Dissertation of University of Ibadan, Ibadan.

Bamidele, E. F. (2003).Effectiveness of Computer Assisted Instruction on the Teaching of Secondary School Practical Chemistry. Unpublished Masters Thesis of Faculty of Education, Obafemi Awolowo University, Ile-Ife.

Colburn, A. (1996). Modifying Laboratory Activities (invited paper). The Science Teacher. 63,1,10

Donovan, M.S., \& Bransford, J.D. (2005). Introduction. HOW STUDENTS learn science in the classroom.

Washington, D.C.: National Academics press, pp. 1-26. Retrieved March 24, 2007 from

http://books.nap_cgi/skimit.cgi?recid=11102\&clp=227-52

Eni Olorunda, T. (2007). Teaching Science to Students with Special Needs. A paper presented In a Workshop organized by the Education Tax Fund for Science Teachers of Secondary Schools in Nigeria held on June 20th.

Igelsrud, D. \& Leonard, W.H. (1988). Lab: What research says about biology lab INSTRUCTION? The American biology teacher, 50(5), 303-306.

Nwagbo, C. (2001). The Relative Efficacy of Guided Inquiry and Expository Methods of Different Levels of Scientific Literacy. The Journal of Science Teachers' Association of Nigeria,6(2), 43-51.

Onanuga, P.A. (2001). Individually prescribed instruction N.Y. John Willey \& sons.

Sanda, O.E. (2005). Modern day Chemistry practical work book with manual. Ibadan, Nigeria: Adeola Printing Press.

Schunk, D.H. (2000). Learning theories: An evaluation perspective. New Jersey. Prentice Hall.

Silber, R.L. (1981). The role of science teaching organizations internationally in education development. The Journal of Science Teachers Association of Nigeria 19(2), 53-55.

Salvin, R. (1990). Cooperative learning. Here to stay or gone tomorrow. Educational leadership, 47(4), 3-7 
Irinoye, J., et al. (2014). Relative Effectiveness of Guided Inquiry and Demontration Methods on Students Performance in Practical Chemistry in Secondary School in Osun State, Nigeria. Advances in Social Sciences Research Journal, 2(2), 21-30.

Vygotsky, L. S. (1978). Mind and Society. The Development of Higher Mental Processes.cambridge, MA: Havard University Press.

West African Examinations Council. (2010). Chief examiners' report on the West African Senior Secondary Certificate Examination in chemistry May/June

EniOlorunda, T. (2007). Teaching science to students with special needs. A paper presented in a Workshop organized by the Education Tax Fund for Science Teachers of Secondary Schools in Nigeria held on June 20th. 